\title{
Some Ecology Features of Poecilia mexicana Steindachner, 1863 (Osteichthyes: Poeciliidae) from Alvarado Lagoonal System, Veracruz, Mexico
}

\author{
Chávez-López Rafael, Rocha-Ramírez Arturo, Cortés-Garrido Horacio \\ Estuarine Nekton Laboratory, Iztacala Faculty of Higher Studies, National Autonomous University of Mexico, Av. de los Barrios No 1 , Los \\ Reyes Iztacala, Tlalnepantla, Estado de Mexico, Mexico
}

\section{Email address:}

rafaelcl@unam.mx (R. Chávez-López), arocha@unam.mx (A. Rocha-Ramírez), horcor@gmail.com (H. Cortés-Garrido)

\section{To cite this article:}

Chávez-López Rafael, Rocha-Ramírez Arturo, Cortés-Garrido Horacio. Some Ecology Features of Poecilia mexicana Steindachner, 1863 (Osteichthyes: Poeciliidae) from Alvarado Lagoonal System, Veracruz, Mexico. American Journal of Life Sciences.

Vol. 3, No. 2, 2015, pp. 76-84. doi: 10.11648/j.ajls.20150302.14

\begin{abstract}
The shortfin molly Poecilia mexicana Steindachner, 1863, has a wide distribution in southeastern Mexico where it inhabits rivers and coastal lagoons. In the Alvarado Lagoonal System, Veracruz, it is distributed towards the northeast in Camaronera Lagoon. The shortfin molly shows an affinity for oligohaline to mesohaline sites with submerged vegetation, well-oxygenated, and transparent water. The major abundance and biomass of this species was obtained during December to February. The diet of Shortfin molly consists principally of algae. Length-frequency distribution shows two size classes as most numerous during all seasons (41 to 50 and 51 to $60 \mathrm{~mm}$ respectively), corresponding to reproductive fish and young of the year; individuals with developed gonads were found throughout the year, although most reproductive adults were found between April and December. The Gonadosomatic Index (GSI) high values were founded in reproductive females. Fecundity ranged from 21 to 116 eggs/female, and 19 to 83 embryos/female.
\end{abstract}

Keywords: Poecilia Mexicana, Freshwater Fish, Alvarado Lagoonal System, Gulf of Mexico

\section{Introduction}

Coastal lagoons and estuaries are regarded as high productive ecosystems as they are subsided by continental and adjacent marine platform hydrological processes, by tides, by sedimentation processes and high rates of autochthone organic production. The combination of these environmental conditions results more advantageous for marine organisms and provides shelter habitats for fish, while at the same time provides abundant food and appropriate breeding zones (Whitfield and Elliot, 2002).

Concerning fresh-water fish, their presence in estuaries and coastal lagoons has been explained due to their tolerance to salinity being restricted and because of this they occupy estuarine zones with low salinity, this is because they are generally known as "organisms dragged by current" (Peterson and Meador, 1994), they are also considered as "visitants" that roam "occasionally" or "adventitiously" (Elliott and Hemingway, 2002), these terms indicate that the occupation of fresh-water fish is almost an accident that would explain a less frequent use of estuaries; and in the best case scenario these organisms use estuaries for reproduction and afterwards return to limnetic habitats; in the context of estuarine fish communities, it is generally perceived that this group contributes minimally to abundance and biomass of fish assemblages (Blabber, 2002).

However, there are fresh-water species which make regular use of estuaries for shelter, seasonal reproductive migrations, breeding and feeding, known as "estuarine opportunists" (Potter et al., 2013) moreover, it is a fact that in fish assemblages composition in estuaries occurrences of fresh-water species happen regularly (Elliot et al., 2007) and keep the same after perturbations such as hurricanes (O'Connell et al., 2014); the presence of fresh-water species in estuarine ecosystems has been registered in template zones of the American Atlantic (Tuckey and Fabrizio, 2013), South America (Jaureguízar et al., 2006; Barletta et al., 2008) and central Gulf of Mexico (Chávez-López et al., 2005a).

The species of the Poeciliidae family are fresh-water 
mostly, they inhabit shallow waters and marginal zones in lakes and rivers; they can colonize a great variety of environments, including salty ones, condition which has been used (and is still used) as a taxonomic criteria (Miller, 1983 for example). Given their great thermal tolerance they can also inhabit water bodies with high temperatures $\left(42-44^{\circ} \mathrm{C}\right)$; in other instances they are also capable of inhabiting places with low concentration of oxygen being able to extract it from the air (Nordlie, 2006; Martin et al., 2009; Tobler et al., 2011).

Poecilia mexicana Steindachner, 1863 has been reported in the Alvarado Lagoonal System (ALS), Chávez-López (1998) placed it as a rare occurrence species during the 1987-1991 period; however, Chávez-López et al., (2005 a and b) remarked that this species has a permanent historical register and has been increasing its abundance in the ALS in recent years. As of today, little is known about the influence of estuarine habitats in the history of the life of the species of fresh water fish that occupy them. In such way, this contribution presents ecologic and reproductive information of $P$. mexicana in ALS during the years 2000-2002.

\section{Material and Methods}

\subsection{Study Area}

The ALS is located in the coastal plain of central Mexican Gulf, $63 \mathrm{~km}$ south of Veracruz port, between $18^{\circ} 43^{\prime} 00^{\prime \prime}-18^{\circ}$ $52^{\prime} 15^{\prime \prime} \mathrm{N}, 95^{\circ} 42^{\prime} 20^{\prime \prime}-95^{\circ} 57^{\prime} 32 \mathrm{~W}$, it is a group of three lagoons: Alvarado Lagoon (AL), Buen País Lagoon (BPL) and Camaronera Lagoon (CL) and the estuarine zone of the Papaloapan River (PR), it occupies an area of 26200 ha, has an average depth of $2.5 \mathrm{~m}$ in the central zone of ALS and an average of $14 \mathrm{~m}$ in the RP channel, water temperature is warm from April to September, between $27^{\circ} \mathrm{C}$ and $33^{\circ} \mathrm{C}$, and it decreases to $22^{\circ} \mathrm{C}$ during the cold months (December to February); salinity varies from 0 to 10 practical salinity units (PSU) in CL between July and October, during this period the highest salinities occur in artificial inlet of CL and the estuarine zone of PR; between November and June it reaches up to 16 PSU in CL, 22 PSU in PR entrance, while the rest of the system presents 0 to 8 UPS in BPL and AL (Morán-Silva et al., 2005).

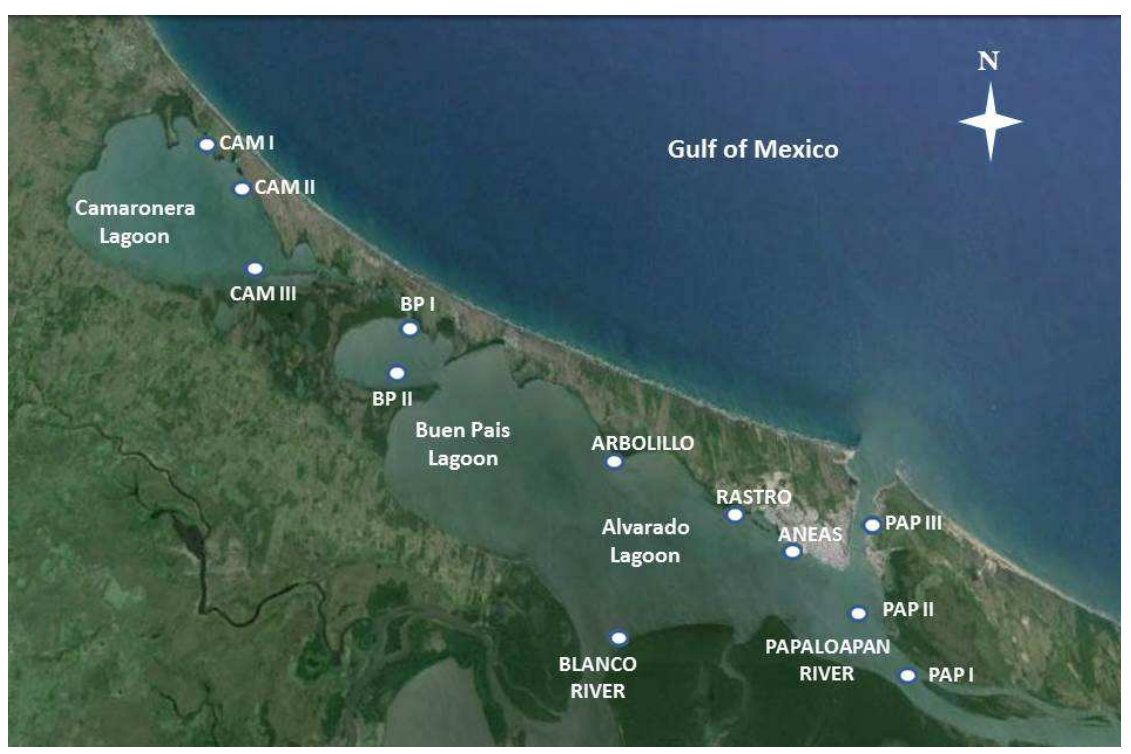

Figure 1. Sampling sites during June 2000-July 2002 in the ALS. Inset map shows approximate geographic location of the study area. Camaronera Lagoon (CL); Buen Pais Lagoon (BPL), Alvarado Lagoon (AL), Blanco River (BL) and Papaloapan River (PR).

The biologic material was obtained from recollections made in ALS by the Project "Fish Communities Ecology in submerged grass prairies", during the 24-month span between June 2000 and June 2002, in 12 stations located in mangrove zones, submerged grass prairies, muddy bottoms and oyster shell reefs (Fig. 1). For the register of physicochemical parameters, each site was geographically located with a Garmin 10X GPS. The following parameters were measured: environment temperature with a Taylor thermometer with a scale of $-10^{\circ} \mathrm{C}$ to $50^{\circ} \mathrm{C}$, salinity, water temperature and conductivity with an YSI-33 salinometer, dissolved oxygen with a YSI-51B oxymeter. Turbidity was measured with a La Motte 2020 turbidimeter, (ntu, nephelometric turbidity units), transparency with a Secchi disc and depth with a sounding line, both registered in centimeters.

\subsection{Specimen Sampling}

Fish were captured at each station using a single haul of a $30 \mathrm{~m}$ long x $2 \mathrm{~m}$ high seine constructed with $6.35 \mathrm{~mm}$ mesh. Total area sampled with each seine haul was $756.25 \mathrm{~m}^{2}$. Fish were fixed in $10 \%$ buffered formalin and also injected in the abdominal cavity in the field to retard the digestive process. Fish were washed in fresh water after one week in formalin and then stored in $70 \%$ ethanol. The specimens were identified in the laboratory according to the identification keys of Álvarez del Villar (1970), Miller (1983) and Miller et al., (2005). All the organisms were measured in standard length (mm), establishing size and weight intervals of $20 \mathrm{~mm}$ and 20 g respectively. All data was classified according to climatic seasonality of the region: Dry season, Rainy season and 
"Nortes" season (Morán-Silva et al., 2005). Furthermore, the coverage percentage of submerged vegetation was visually estimated using a $40 \times 40 \mathrm{~cm}$ square frame.

\subsection{Gonadic Maturity}

To describe the gonadic maturity, 587 organisms were examined; the number of organisms per season was: in Rainy season of 2000, 76 specimens; in North season of 2000-2001, 48 specimens; in Dry season of 2001, 100 specimens; in North season of 2001-2002, 304 organisms and Dry season 2002, 59 specimens. Gonadic maturity and levels of embryonic development were established according to the criteria proposed by Haynes (1995) and Riesch et al., (2011).

The gonads of 100 males and 100 females were extracted and weighted; the gonadosomatic index (GSI) was estimated from this sub-sample, taking into account each organism's weight, the standard length (SL) and the weight of the gonad (Urriola et al., 2004); in the female gonads the oocytes and developed embryos were counted. Fecundity was estimated as the number of mature oocytes inside the female's gonad and fertility as the number of embryos in the celomic cavity.

\subsection{Analysis of Diets}

Dietary composition was determined by dissecting 172 digestive tracts, from which only the first quarter of the intestine was used, and subsequently observed under the stereoscopic microscope. Item food identification was made on the lowest possible taxonomical level. The grid numerical method was used to quantify the intestinal content, where it is assumed that the area each item occupies in the grid is proportional to its volume, estimating the relative proportion

of each identified item, which then is multiplied times the area it occupied in the grid. The analysis of diets was made on a global scale, sorting by size, sex and season (Trujillo-Jiménez and Toledo, 2007; Gido and Franssen, 2007).

\subsection{Statistical Analysis}

The relationship between the presence and abundance of $P$. mexicana according to the physicochemical variables and the coverage percentage of submerged vegetation was examined, considering a two-stage procedure: in the first stage, the collecting locations were classified in relation to the seven physicochemical variables using Principal Components Analysis (PCA) of the correlation matrix with varimax rotation to maximize the results of the download (Sokal and Rohlf, 1995). In the second stage, a tridimensional chart was made, where the first two axes correspond to the two main components which explained the greatest variance of the register, the third axis corresponds to the interval of abundance per each collecting of $P$. mexicana. Only the variables which contributed significantly (absolute value $>0.40$ ) to the interpretation of each principal component were considered. All math analysis were done using the program SPSS (Statistical Package for Social Sciences, 2010) and the results were considered significant if $p<0.05$. Moreover, the Mann-Whitney $U$ test was used with a significance of $p<0.05$ for comparing the values of physicochemical variables of water among the locations where the presence of $P$. mexicana was registered in contrast to the places where the species was not collected.

\section{Results}

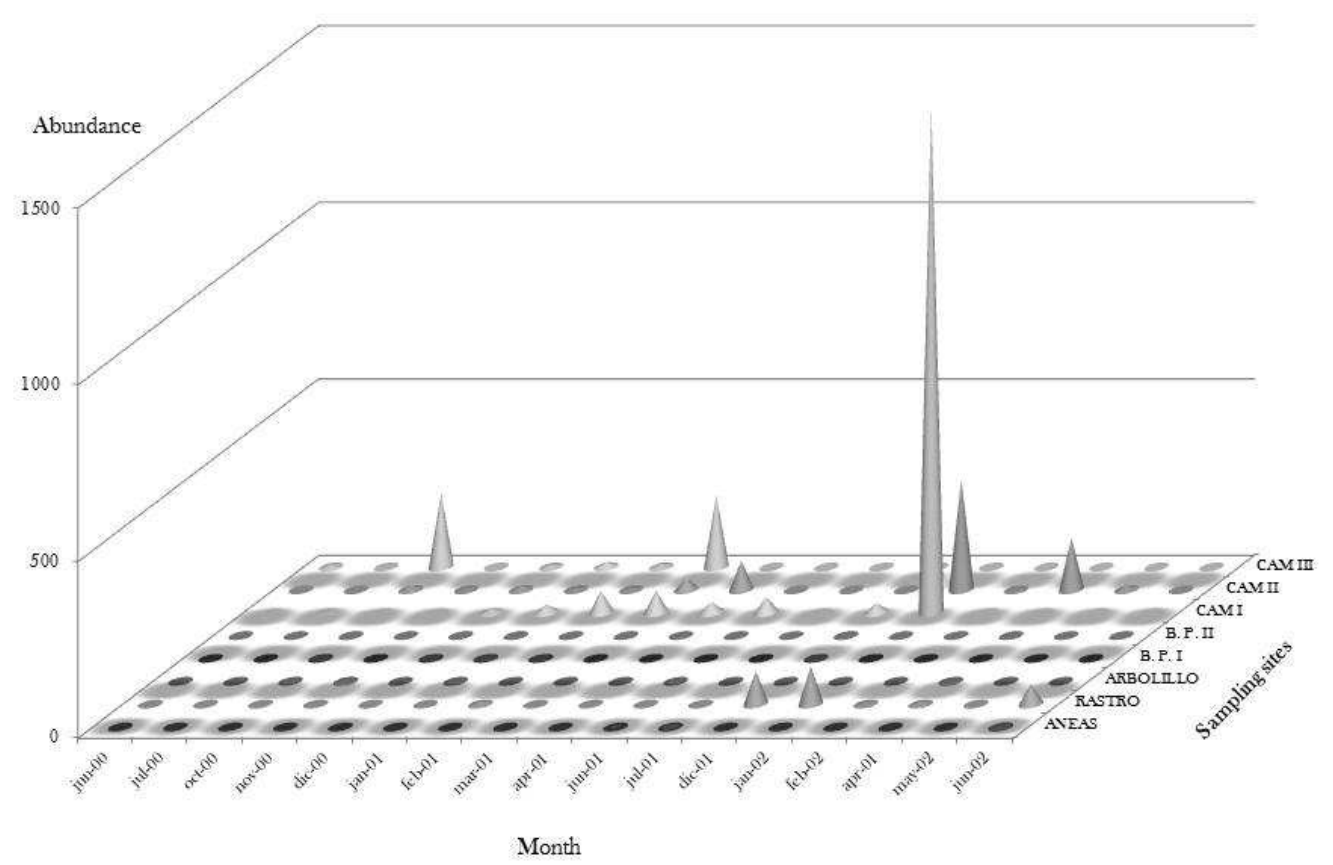

Figure 2. Abundance of Shortfin molly P. mexicana in ALS. Dry season was March through June; the rainy season was July through October; and the "Nortes" season was November through February. 
Table 1. Abundance of P. mexicana expressed as: 1) a percentage of the individuals collected, 2) as percentage in stations with $<50 \%$ coverage with submerged aquatic vegetation (SAV), 3) as percentage in stations with about $50 \%$ coverage with $S A V$, and 4) as a percentage in stations with $>50 \%$ coverage with SAV. Sampling stations correspond to stations on Figure 1, this analysis do not include Blanco River and Papaloapan River sampling stations due to P. mexicana absence through study.

\begin{tabular}{llllllllll}
\hline & Cam I & Cam II & Cam III & BPI & BPII & Arbolillo & Rastro & Aneas & Total \\
\hline $\begin{array}{l}\text { Overall abundance } \\
\text { Stations with }\end{array}$ & 27.1 & 17.1 & 51.5 & 1.3 & 0.5 & 0.9 & 1.3 & 0.3 & 100.00 \\
SAV $<50 \%$ & & & & & & 0.9 & 0.3 & 0.3 & 28.7 \\
SAV $=50 \%$ & 27.1 & & 25.4 & & 0.2 & & & 25.6 \\
SAV $<50 \%$ & & & & & 0.9 & 0.3 & 0.3 & 28.6 \\
\hline
\end{tabular}

Poecilia mexicana was collected on almost all of ALS (except the stations of Blanco River and the ones located in Papaloapan River). A total of 3,086 organisms were captured (Fig. 2). Spatially, the highest register was obtained in LC with a total of $2,761(89.5 \%)$, in second term AL with 300 $(9.7 \%)$ and BPL with $25(0.8 \%)$. The highest incidence of the species occurred during the Nortes season with a total of 2,169 (70.3\%), followed by Dry season with 690 (22.4\%) and Rainy season in which the register was minimum with 227 (7.4\%) (Table 1).

Total biomass of $P$. mexicana during the studied period was $9,445.5 \mathrm{~g}$, the highest biomass was registered in CL with $7,484.9 \mathrm{~g}$, the second highest was AL with $1,844.7 \mathrm{~g}$ and then LBP with $94.8 \mathrm{~g}$. Seasonally, the highest register was obtained during North Season, 2001 with 3,167.3g, and the lowest season was Rainy Season, 2001 with $7.6 \mathrm{~g}$.

Poecilia mexicana was collected in the northeast zone of ALS, particularly from CL where the $90 \%$ of the captured specimens where registered. No individuals where collected in the intermediate zone of LBP, over the internal sand bar side of AL and in the river-influenced zones of BR and PR. $71 \%$ of individuals were captured in zones with more than $50 \%$ of vegetation coverage, dominated by Ruppia maritima Linnaeus, 1753; in the zones of CL and BPL, the Ruppia maritima beds were found to be mixed with the algae species Gracillaria verrucosa (Hudson) Papenfuss, 1950 and Rhizoclonium hieroglyphicum (C. Agardh) Kützing, 1845.

Three axis were extracted from PCA which were equal to the $66.86 \%$ of the total variance of the physicochemical variables (Fig. 3), the results were interpreted in terms of ecologic evidence; given that the variance percentage explained in PCA does not predict the ecologic utility of a particular main component; it was interpreted that the two primary components separate the zones with and without submerged vegetation. It was determined from this analysis that the zones where the highest abundance of $P$. mexicana was collected were characterized for presenting higher transparency, dissolved oxygen concentration, coverage of submerged vegetation and depth, which represent the hydrologic characteristics which prevail during the Nortes and Dry Seasons (Table 2).

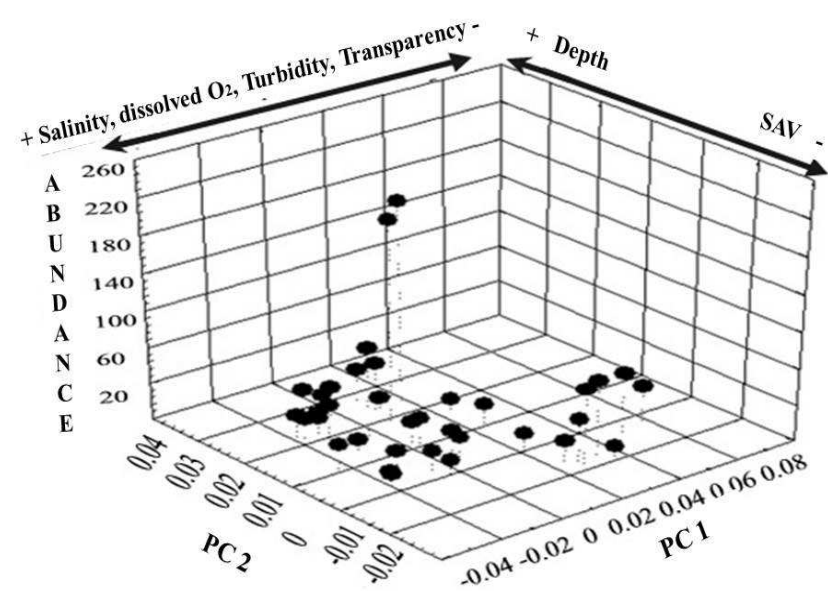

Figure 3. Three-dimensional plot of the standardize factor scores for the stations and months of collection and the abundance of shortfin molly $P$. mexicana arranged on principal components I and II based on seven physicochemical variables.

Table 2. Physicochemical variables correlated to the 3 principal components with eigenvalues $>1$. The percent of variance explained by each component is in parenthesis. Variables with correlations $>0.50$ are used identifying the components.

\begin{tabular}{llll}
\hline & $\begin{array}{l}\text { CP-I } \\
\mathbf{( 3 1 . 1 8 \% )}\end{array}$ & $\begin{array}{l}\text { CP-II } \\
\mathbf{( 2 0 . 2 6 \% )}\end{array}$ & CP-III (15.35\%) \\
\hline submerged vegetation & 0.185 & -0.658 & 0.356 \\
Depth & 0.008 & 0.866 & 0.131 \\
Transparency & 0.684 & 0.413 & 0.179 \\
Salinity & 0.766 & -0.189 & 0.145 \\
Dissolved Oxygen & 0.699 & -0.001 & -0.287 \\
Temperature & 0.001 & -0.003 & 0.915 \\
Turbidity & -0.794 & -0.005 & -0.005 \\
\hline
\end{tabular}

Generally, the comparison of the physicochemical variables among the zones with absence or presence of $P$. mexicana did not show significant differences (Table 3, U Mann-Whitney, $p<0.05$ ); however, the statistical analysis of each variable signaled significant differences in salinity, dissolved oxygen concentration and vegetal coverage (Table 3).

Poecilia mexicana showed affinity of zones with a mesohaline condition, such as CL and BPL during the Nortes and Dry Seasons, and despite its fresh-water origin, the abundance of species decreased during Rainy Season. 
Table 3. Comparison of physicochemical factors (average $\pm \delta$ ) between habitats with and without P. mexicana. Significant difference* $(p<0.05)$ determined by a Mann-Whitney U test.

\begin{tabular}{llll}
\hline Parameter & All stations & Sites with P. mexicana & Sites without P. mexicana \\
\hline Submerged Vegetation (\%)* & $41.35 \pm 34.5$ & $57.14 \pm 32.34$ & $37.76 \pm 32.24$ \\
Depth $(\mathrm{cm})$ & $99.11 \pm 82.9$ & $71.82 \pm 28.8$ & $108.2 \pm 92.6$ \\
Secchi Transparency $(\mathrm{cm})$ & $43.9 \pm 21.9$ & $42.24 \pm 14.7$ & $44.46 \pm 23.9$ \\
Salinity* (psu) & $5.72 \pm 5.7$ & $8.1 \pm 4.2$ & $4.93 \pm 5.9$ \\
Dissolved Oxygen (mg/l)* & $9.39 \pm 1.8$ & $9.83 \pm 1.4$ & $9.25 \pm 1.9$ \\
Temperature $\left({ }^{\circ} \mathrm{C}\right)$ & $27.8 \pm 2.9$ & $26.42 \pm 3.5$ & $28.27 \pm 2.6$ \\
Turbidity (NTU)* & $17.35 \pm 14.9$ & $14.81 \pm 11.3$ & $18.39 \pm 16.5$ \\
\hline
\end{tabular}

The size range of $P$. mexicana was registered in an interval of 11 to $100 \mathrm{~mm}$, the greatest number of organisms was gathered in the $41-50 \mathrm{~mm}$ and the $51-60 \mathrm{~mm}$ intervals in all the studied zones. In the Nortes Season all size ranges were present, the one with the highest organism count was the 41-50mm interval with 914 specimens (Fig.4), followed by the $51-60 \mathrm{~mm}$ interval up to the $81-90 \mathrm{~mm}$ interval with counts of 513, 270, 168 and 44 organisms respectively. During the Dry Season all size ranges were collected, most abundant was the $51-60 \mathrm{~mm}$ range with 74 organisms.
Concerning gonadic maturity, during the Rainy Season of 2000, development stages 2, 3, 4-6 and 7-8 were present, the latter for females with developing embryos, 24 specimens were located in the 4-6 stages, followed by stage 2 with 23 , stages 7-9 with 16 and finally stage 3 with 13 organisms; during the North Season of 2002, organisms appeared in the stages 1, 2, 3, 4-6 and 7-9 with 25, 87, 98, 64 and 31 organisms respectively. During the Dry Season of 2001, stage 2 outnumbered followed by stages $3,4-6,7-9$ and 1 (Fig.5).

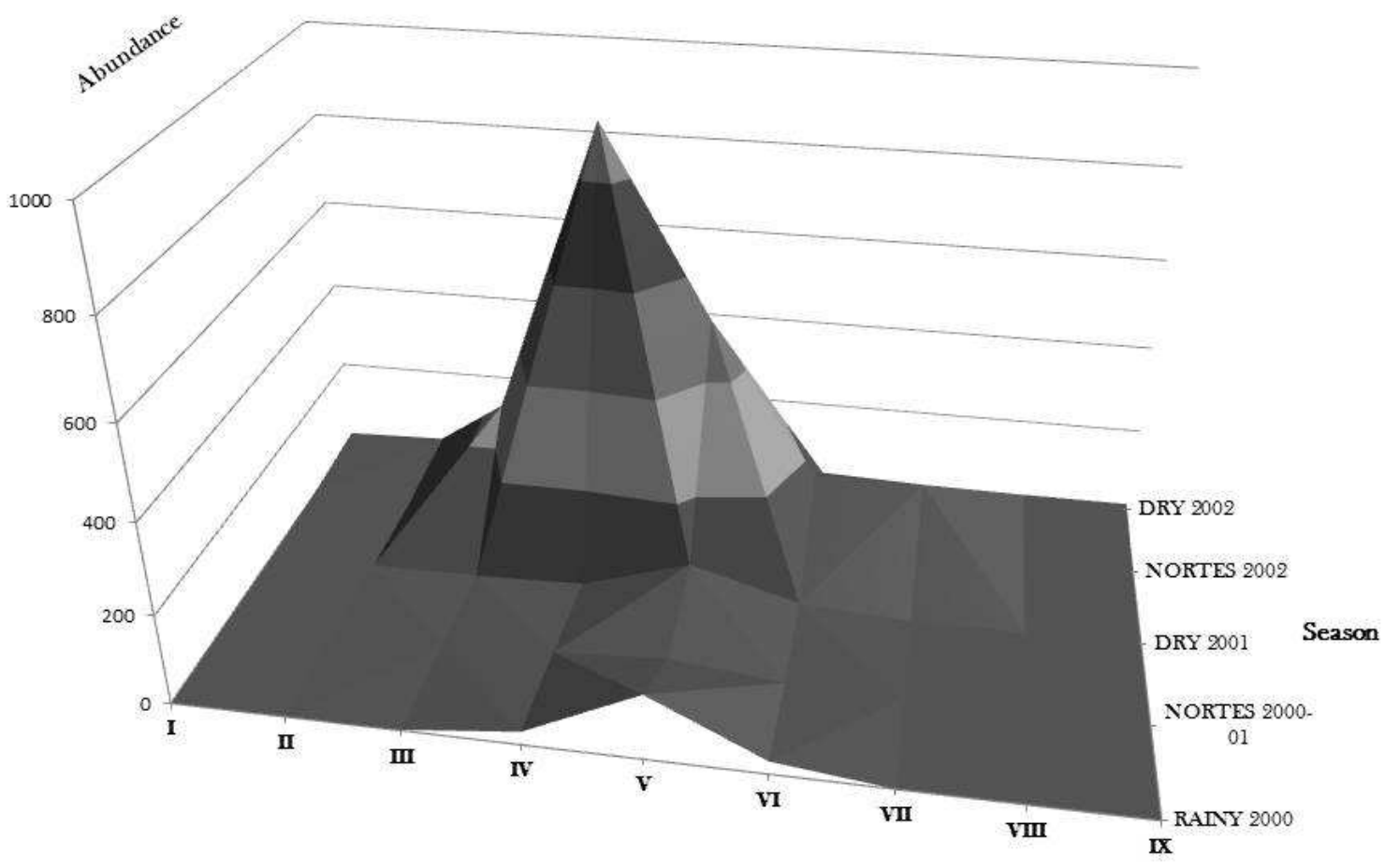

Size Class

Figure 4. Size distribution of P. mexicana by season in ALS. Dry season was March through June; the rainy season was July through October; and the Nortes season was November through February. 


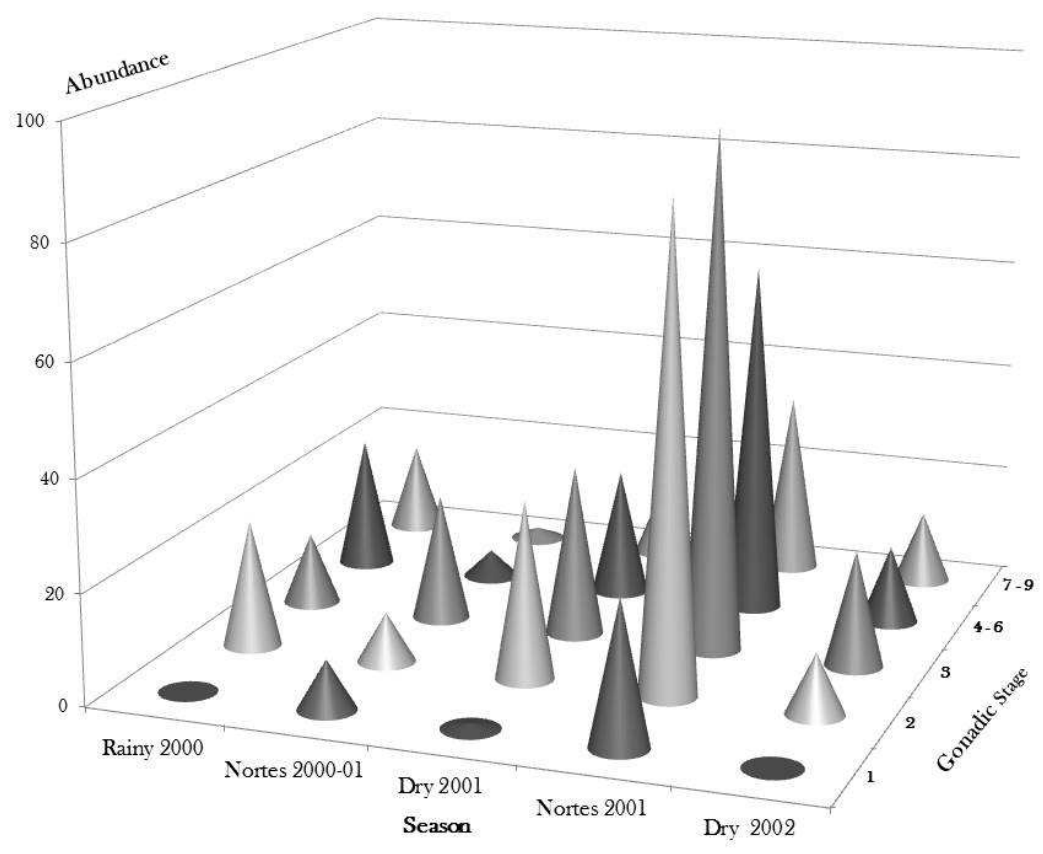

Figure 5. Seasonal gonadic growth stages of P. mexicana from the ALS.

Fecundity was registered in females of size range of $31-84 \mathrm{~mm}$ of LP, in a weight range of $3.2-13.78 \mathrm{~g}$ and in stages 3-4 of gonadic maturity. The quantity of oocytes was registered in an interval of 21 to 116 oocytes per female, with an average of $56.64( \pm 24.34 \mathrm{sd})$ fecundity did not statistically related to female size (Number of oocytes in gonad $=5.049 \mathrm{LP}$ $+1.3439, \mathrm{R}^{2}=0.254$ ).

Fertility was quantified in females with a size interval between $51-80 \mathrm{~mm}$ of LP and a weight interval between 3.6 and $17.8 \mathrm{~g}$. The number of embryos was registered in an interval of 19-83, with an average of $58.97( \pm 18.61 \mathrm{sd})$. Embryonic development was identified among stages 4 to 6 , which are characterized by the presence of the blastodisc up to the formation of ocular cups, and stages 7 to 9 in which the tail and the eyes grow and the lateral line pigmentation appears (Haynes, 1995; Riesch, et al., 2011), no embryos in advanced development stages were found. Female fertility did not relate significantly with longitude (Embryo number $=2.31 \mathrm{LP}+$ $1.725, \mathrm{R}^{2}=0.199$ ).

The GSI values demonstrated that the female makes an energy investment for reproductive purposes throughout the year, given that during the Rainy and Nortes seasons' months (August to February) the highest values were found, which indicate the most intense reproductive activity. The lowest and highest values during the different climatic seasons were: Rainy Season of 2000, 0.56 and 21.55. Dry Season of 2001 1.45 and 17.71; during the North Season of 2002 the lowest GSI was 0.05 and the highest was 23.78 (Fig. 6).

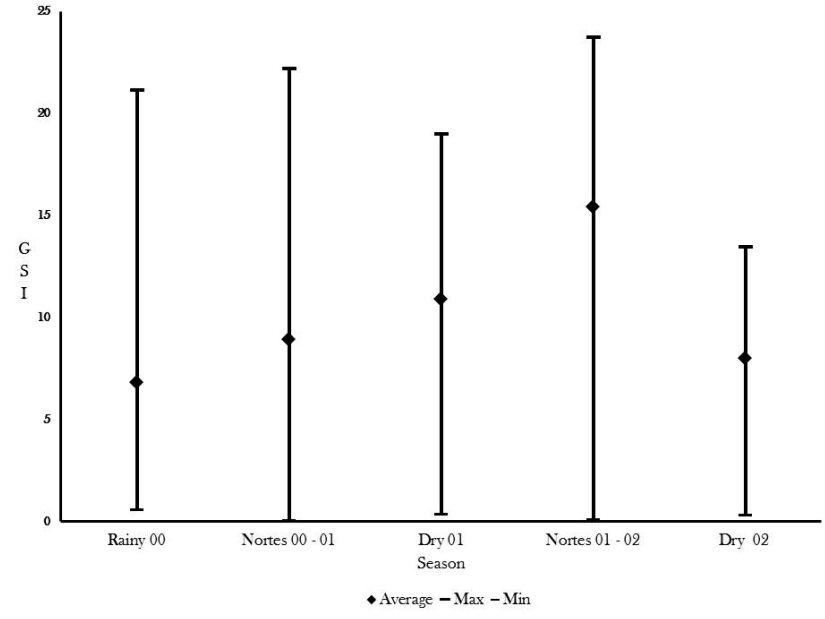

Figure 6. Plot of the gonadosomatic index (GSI) by season of P. mexicana caught from the ALS.

Shortfin molly's diet is composed of two alimentary types: diatoms and unidentified vegetal matter (UVM), detritus and sediments were also registered in variable quantities. Observed diatoms were of the centric type, but most of them belonged to the order of the pennales, of the genus Cymbella, Fragilaria, Navicula, Nitzschia and Surinella. In the UVM, remains of algae debris and $R$. maritima were observed, the species diet composition was presents the same alimentary composition during all seasons. The difference lied on the minimal proportions of complementary food items consumed foodstuff, the previous allows to identify $P$. mexicana as a primary herbivore consumer (Fig. 7). 


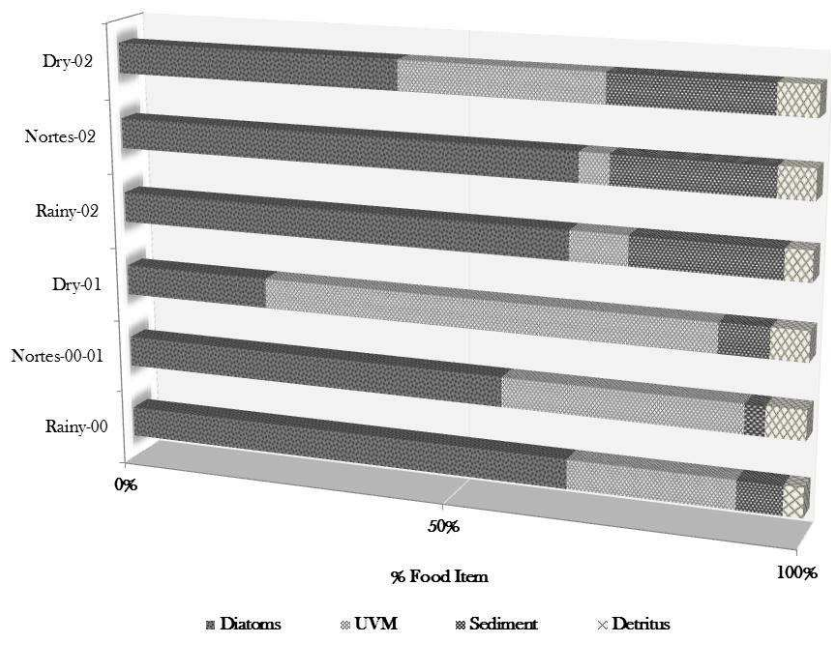

Figure 7. Seasonal diet composition (\% weight) of P. mexicana in ALS.

\section{Discussion}

Poecilia mexicana is a fresh-water species, that given its occurrence frequency, is a resident of ALS (Chávez-López et al., 2005a). Nowadays, information about the presence of $P$. mexicana in coastal lagoons and estuaries is scarce, despite that Miller (1983) used this ecologic character to separate it from other congeneric species. In this regard, different studies on molecular phylogenies have showed this separation among Poecilia gillii Knerr, 1863, Poecilia orri Fowler, 1943, Poecilia catemaconis Miller, 1975, Poecilia latipunctata, Meek, 1904, Poecilia sulphuraria Álvarez, 1948 and specially from Poecilia sphenops, Valenciennes, 1846, (Ptacek and Breden, 1998; Doadrio, et al., 2009; Alda, et al., 2013).

In ALS, P. mexicana presented affinity towards zones with submerged vegetation with mesohaline characteristics, high transparency and well-oxygenated water; this explains its distribution towards the northeastern zone of the system, particularly in CL where the highest abundances during Nortes and Dry Seasons occurred. It is worth mentioning that despite its fresh-water origin, the abundance of the species was lower during Rainy Season, when limnetic, oligohaline, and high turbidity conditions prevail; in the zones where $P$. mexicana appeared, water turbidity was lower, the influence of this factor would explain its absence during Rainy Season.

Same as $P$. mexicana, several of fresh-water species guild of ALS maintain affinity for zones with these hydrologic characteristics, for instance, during the investigation, species such as Cichlasoma urophthalmus (Günther, 1862), Thorichthys helleri (Steindachner, 1864) Petenia splendida Günther, 1862, were also registered with higher abundance in this areas of SLA, even more than those sites with limnetic and oligohaline water such as in the mouths of rivers Blanco, Acula, Papaloapan and their influence zones (Chávez-López et al., 2005b).

It has been experimentally demonstrated that species of this family, as $P$. formosa for instance, tolerate high salinities and are able to survive in marine-water salinity conditions, in other instances, Poecilia latipinna Lesueur, 1821 and Poecilia reticulata Peters, 1859 also showed similar tolerance (Nordlie,
2006). P. mexicana has been reported in coastal lagoons of Veracruz such as the Tamiahua Lagoon, (Franco-López and Chávez-López, 1991), the Pueblo Viejo Lagoon (Castillo-Rivera, et al. 2011) and the Sontecomapan Lagoon (Rodríguez-Varela, et al. 2010).

Lindholm et al. (2005), considered that the success of the Poeciliidae family for invading and adapting to new environmental conditions, is due to their high genetic diversity that they present; for example, $P$. mexicana has been found in extreme condition habitats such as cave waterholes and sulfurous water ponds, in which just a few fish species manage to survive (Plath et al., 2006; Plath et al., 2007). Kelley et al., (2012) have revealed the presence of candidate genes which enable responses to stressful physicochemical factors such as heat shock and oxidative stress response proteins, in addition to candidate genes for responding to hypoxic inductions.

Poecilia mexicana presented a fecundity range of 21 to 116 eggs/female with an average of 59.7, in contrast to those average values reported by Urriola et al., (2004) for other species of Poeciliidae: $P$. reticulata (49 eggs/female), Poeciliopsis occidentalis Baird \& Girard, 1853 (10.1 eggs/female), Poeciliopsis turrubarensis Meek, 1912 (18.6 eggs/female) and Gambusia gaigei Hubbs, 1929 (50 eggs/female or more). Concerning fertility (56.9 embryos/female), it is comparable to $P$. reticulata with 56.1 embryos/female, but surpasses the register of $P$. turrubarensis (40 embryos/female), only P. latipinna (68.2 embryos/female) has reported a higher average.

There was no significant correlation between size and fecundity nor between size and fertility of the species, this fact has also been reported in $P$. reticulata, Heterandria formosa Girard, 1859, Poeciliopsis elongata Günther, 1866 and $P$. turrubarensis; in these species, the absence of said correlation can be explained by the high degree of matrotrophy and superfetation in them, given that they can present oocytes, ovules, eggs and embryos simultaneously (Urriola et al., 2004). In this study, females of $P$. mexicana also showed this condition.

The highest GSI were registered during the transition of Nortes and Dry seasons, during this time span, $P$. mexicana females make a greater reproductive expense, which happens with other fresh-water species of ALS; for example, $C$. urophthalmus (Chávez-López et al., 2005b). Also, incipient matrotrophy and superfetation offers advantages to the population in environmental stress conditions, which in this case can be associated to the variation in salinity (Riesch et al., 2010).

The herbivore trophic function of $P$. mexicana in ALS is that of an energy transformer from primary sources, which promotes energy transference through trophic webs. Until now, no information about $P$. mexicana's diet in coastal ecosystems was available; generally, it is assumed that poeciliids present great plasticity which allows them to include different foods in their diet and occupy different trophic levels (Trujillo-Jiménez and Toledo, 2007).

The usage of estuarine habitats by fresh-water species is a polemic matter yet (Potter, et al., 2013), it has been shown that 
the occurrence of $P$. mexicana in the ALS, rather than being just an opportunistic or facultative usage of estuarine habitats by a fresh-water species, it indicates its tendency to occupy low salinity, transparent and well oxygenated zones, where it manages to reproduce taking advantage of its matrotrophic qualities and its wide tolerance to typical environmental dynamics of a coastal lagoon, where it also participates as a primary consumer; this evidence confirms the ability of $P$. mexicana to colonize saline aquatic habitats in a successful way.

\section{Acknowledgements}

We are grateful to M. R. Chávez Miranda for help us in the manuscript and Horacio Vazquez-López for their comments. The División de Investigación of our institution partially provided financial support for this project. This manuscript was benefited with the valuable comments from the anonymous reviewers.

\section{References}

[1] Whitfield A.K. and M. Elliot, 2002. Fishes as indicators of environmental and ecological changes within estuaries: A review of progress and some suggestions for the future. Journal of Fish Biology, 61: 229-250.

[2] Peterson M.S. and M.R. Meador, 1994. Effects of salinity on fresh water fishes in coastal plain drainages in the Southeastern U S. Reviews in Fisheries Science, 2(2): 95-121.

[3] Elliot M. and K. Hemingway, 2002. Fishes in estuaries. Blackwel Science Ltd./Blackwell Science: London. ISBN 0-632-05733-5. XX, $636 \mathrm{pp}$.

[4] Blabber S.J.M., 2002. "Fish in hot water": the challenges facing fish and fisheries research in tropical estuaries. Journal of Fish Biology, 61(Supplement A):1-20.

[5] Potter I.C., J.R. Tweedley, M. Elliott and A.K. Whitfield, 2013. The ways in which fish use estuaries: a refinement and expansion of the guild approach. Fish and Fisheries. http://onlinelibrary.wiley.com/doi/10.1111/faf.12050/full

[6] Elliott M., A.K. Whitfield, I.C. Potter, S.J.M. Blaber, D.P. Cyrus, F.G. Nordlie and T.D. Harrison, 2007. The guild approach to categorizing estuarine fish assemblages: a global review. Fish and Fisheries, 8: 241-268.

[7] O'Connell M.T., A.M. O'Connell and C.S. Schieble, 2014. "Response of Lake Pontchartrain fish assemblages to hurricanes Katrina and Rita". Estuaries and Coasts 37(2): 461-475.

[8] Tuckey T.D. and M.C. Fabrizio, 2013. Influence of survey design on fish assemblages: Implications from a study in Chesapeake Bay tributaries. Transactions of the American $\begin{array}{llll}\text { Fisheries } & \text { Society, } & \text { 142(4): } & \text { 957-973. }\end{array}$ DOI:10.1080/00028487.2013.788555

[9] Jaureguízar A.J., R. Menni, C. Lasta and R. Guerrero, 2006. Fish assemblages of the northern Argentine coastal system: spatial patterns and their temporal variations. Fisheries Oceanography, 15(4): 326-344.

[10] Barletta M., C.S. Amaral, M.F.M. Correa, F. Guebert, D.V.
Dantas, L. Lorenzi and U. Saint-Paul, 2008. Factors affecting seasonal variations in demersal fish assemblages at an ecocline in a tropical-subtropical estuary. Journal of Fish Biology, 73: 1314-1336.

[11] Chávez-López R., M.S. Peterson, N.J. Brown-Peterson, A.A. Morales-Gómez and J. Franco-López, 2005a. Ecology of the Mayan cichlid Cichlasoma urophthalmus Günther, in the Alvarado Lagoonal System, Veracruz, Mexico. Gulf and Caribbean Research, 17:123-131.

[12] Miller R.R., 1983. Checklist and key to the mollies of Mexico (Pisces: Poeciliidae: Poecilia, Subgenus Mollienesia). Copeia, (3): 817-822. Published by: American Society of Ichthyologists and Herpetologists (ASIH) Stable URL: http://www.jstor.org/stable/1444354

[13] Nordlie F G., 2006. Physicochemical environments and tolerances of cyprinodontoid fishes found in estuaries and salt marshes of eastern North America. Review of Fish Biology, 16(1): 51-106.

[14] Martin S., A. Hitch, K. Purcell, P. Klerks and P. Leberg, 2009. Life history variation along a salinity gradient in coastal marshes. Aquatic Biology, 8: 15-28.

[15] Tobler, M., M. Palacios, L.J. Chapman, I. Mitrofanov, D. Bierbach, M. Plath and M. Mateos, 2011. Evolution in extreme environments: replicated phenotypic differentiation in livebearing fish inhabiting sulfidic springs. Evolution: International. Journal of Organic Evolution, 65(8): 2213-28.

[16] Chávez-López R., 1998. Caracterización ecológica de la comunidad de peces asociados a praderas de Ruppia maritima en el Sistema lagunar de Alvarado Veracruz. Tesis de Maestría en Ciencias. Facultad de Ciencias, Universidad Nacional Autónoma de México. México.145 p.

[17] Chávez-López R., J. Franco-López, A. Morán-Silva and M.S. O'Connell, 2005b. Long-term fish assemblage dynamics of the Alvarado Lagoon Estuary, Veracruz, Mexico. Gulf and Caribbean Research, 17:145-156.

[18] Morán-Silva A., F.L.A. Martínez, R. Chávez-López, E.F. Contreras, M.F. Gutiérrez, M.S. Peterson and N.J. Brown-Peterson, 2005. Seasonal and spatial patterns in salinity, nutrients, and chlorophyll a in the Alvarado Lagoonal System, Veracruz, Mexico. Gulf and Caribbean Research, 17:133-143.

[19] Álvarez del Villar J., 1970. Peces mexicanos (claves). Secretaria de Industria y Comercio. Dirección General Piscicultura. $167 \mathrm{p}$.

[20] Miller R.R., W.L. Minckley and S.M. Norris, 2005. Freshwater fishes of Mexico. The University of Chicago Press. $490 \mathrm{p}$.

[21] Haynes J.L., 1995. Standardized classification of Poeciliid development for life-history studies. Copeia, 1: 147-154. Published by: American Society of Ichthyologists and Herpetologists (ASIH). Stable URL: http://www.jstor.org/stable/1446809

[22] Riesch R., I. Schlupp, R.B. Langerhans and M. Plath, 2011. Shared and unique patterns of embryo development in extremophile poeciliids. PLoS ONE, 6(11): e27377. doi:10.1371/journal.pone.0027377

[23] Urriola H.M., P.J. Cabrera and M. Protti, 2004. Fecundidad, fertilidad e índice gonadosomático de Poecilia reticulata (Pisces: Poeciliidae) en un estanque en Heredia, Costa Rica. Revista de Biología Tropical, 52(4): 945-950. 
[24] Trujillo-Jiménez P. and B.H. Toledo, 2007. Alimentación de los peces dulceacuícolas tropicales Heterandria bimaculata y Poecilia sphenops (Cyprinidontiformes: Poeciliidae). Revista de Biología Tropical, 55(2): 603-615.

[25] Gido K. and N. Franssen, 2007. "Invasion of stream fishes into low trophic positions". Ecology of Freshwater Fishes, 16: 457-464.

[26] Sokal R.R. and F.J. Rohlf, 1995. Biometry. 3rd. Ed. W. H. Freeman and Co. New York. 887 p.

[27] SPSS, 2010. (SPSS) for Windows. V. 10. Chicago, Ill. Statistical Package for Social Sciences Inc.

[28] Ptacek M.B. and F. Breden, 1998. Phylogenetic relationships among the mollies (Poeciliidae: Poecilia: Mollienesia group) based on mitochondrial DNA sequences. Journal of Fish Biology, 53(sA): 64-81.

[29] Doadrio I., S. Perea, L. Alcaraz and N. Hernández, 2009. Molecular phylogeny and biogeography of the Cuban genus Girardinus Poey, 1854 and relationships within the tribe Girardinini (Actinopterygii, Poeciliidae). Molecular Phylogenetics and Evolution, 50: 16-30.

[30] Franco-López J. and R. Chávez-López, 1991. Síntesis sobre el conocimiento de la ictiofauna de la laguna de Tamiahua, Veracruz, México. Hidrobiológica, 3-4: 53-63.

[31] Alda F., R.G. Reina, I. Doadrio and E. Bermingham, 2013. Phylogeny and biogeography of the Poecilia sphenops species complex (Actinopterygii, Poeciliidae) in Central America. Molecular Phylogenetics and Evolution, 66: 1011-1026.
[32] Castillo-Rivera M., S. Ortiz-Burgos and R. Zárate-Hernández, 2011. Estructura de la comunidad de peces estuarinos en un hábitat con vegetación sumergida: variación estacional y nictemeral. Hidrobiológica, 21(3): 311-321.

[33] Rodríguez-Varela A.C., A. Cruz-Gómez and H. Vázquez-López, 2010. List of the ichthyofauna in the Sontecomapan Lagoon, Veracruz, México. BIOCYT, 3(9): 107-121.

[34] Lindholm K.A., F. Breden, H.J. Alexander, C. Woon-Khiomg, G.T. Sumita and R. Brooks, 2005. Invasion success and genetic diversity of introduced populations of guppies Poecilia reticulata in Australia. Molecular Ecology, 14(12): 3671-3682.

[35] Plath M., M. Tobler, R. Riesch, F.J. García de León and I. Schlupp, 2006. "Evolutionary biology in Cueva Villa Luz: Ichthyological research in a sulfidic cave in Tabasco". AMCS Activities Newsletter, 69: 64-68.

[36] Plath M., M. Tobler, R. Riesch, F.J. García de León, O. Giere and I. Schlupp, 2007. Survival in an extreme habitat: the roles of behavior and energy limitation. Naturwissenschaften, 94: 991-996.

[37] Kelley J.L., C.N. Passow, M. Platt, L.A. Rodriguez, M. Ching-Yee and M. Tobler, 2012. Genomic resources for a model in adaptation and speciation research: characterization of the Poecilia mexicana transcriptome. BMC Genomics, 13: 652. doi:10.1186/1471-2164-13-652

[38] Riesch R., M. Plath, I. Schlupp and E. Marsh-Matthews, 2010. Matrotrophy in the cave molly: an unexpected provisioning strategy in an extreme environment. Evolutive Ecology, 24: 789-801. 